\title{
CLINICO-HAEMATOLOGICAL STUDY OF IRON DEFICIENCY ANAEMIA AND B-THALASSEMIA TRAIT- PREDICTIVE VALUE OF SEHGAL INDEX AND VARIOUS COMPLETE BLOOD COUNT INDICES TO DISCRIMINATE BETWEEN IRON DEFICIENCY ANAEMIA AND B-THALASSEMIA TRAIT AND CONFIRMATION USING HAEMOGLOBIN ELECTROPHORESIS/HPLC
}

\author{
Priya Jaswani ${ }^{1}$, Rajendra Kumar Nigam², Suhas Kothari ${ }^{3}$
}

1 Postgraduate Student, Department of Pathology, Gandhi Medical College, Bhopal, Madhya Pradesh.

2Professor, Department of Pathology, Gandhi Medical College, Bhopal, Madhya Pradesh.

3 Associate Professor, Department of Pathology, Gandhi Medical College, Bhopal, Madhya Pradesh.

ABSTRACT

\section{BACKGROUND}

The most frequent hypochromic microcytic anaemias are iron deficiency anaemia and $\beta$-thalassemia. It is estimated that about $50 \%$ of the world's population with $\beta$-Thalassemia trait are in Southeast Asia. Thalassemia traits are commonly misdiagnosed and treated as iron deficiency anaemias, in which iron is not required. It causes both economic and health burden to the patient. The excess iron has toxic effects on the body. The purpose of using indices to discriminate anaemia is to detect subjects who have a high probability of requiring appropriate follow-up and to reduce unnecessary investigative costs.

Aims and Objectives-

1. To study red blood cell indices and peripheral smear examination in microcytic hypochromic anaemia.

2. Estimation of HbA2 levels (Using Haemoglobin Electrophoresis/ HPLC) and Serum ferritin levels of all cases and confirmation of $\beta$-Thalassemia trait and Iron deficiency anaemia cases.

3. To evaluate the diagnostic value of various RBC indices in diagnosing $\beta$-Thalassemia trait and Iron deficiency anaemia.

4. To evaluate the Sehgal index and compare it to existing complete blood count based indices.

\section{MATERIALS AND METHODS}

It is a prospective observational study carried out from January 2016 to June 2017 in Central Pathology Lab, Department of Pathology, Gandhi Medical College and Hamidia Hospital, Bhopal (Madhya Pradesh). Serum ferritin and HbA2 values were determined in all 100 cases. Values of $\mathrm{Hb}, \mathrm{RBC}$ count, MCV, MCH and RDW obtained from the electronic cell counter were used to calculate discrimination indices by various mathematical formulae. Sensitivity, specificity, positive predictive value (PPV), negative predictive value (NPV) and Youden's index (YI) were calculated for all the nine discriminants.

\section{RESULTS}

In the present study the Sehgal index showed a reasonably high sensitivity, specificity and good Youden's index of $100 \%, 90.59 \%$ and $90.59 \%$ respectively. This was followed by Mentzer index which showed sensitivity, specificity and Youden's index of $93.3 \%$, $97.65 \%$ and $90.9 \%$ respectively.

\section{CONCLUSION}

The present study was performed to promote screening programs to detect $\beta$-thalassemia trait. Here, common haematological indices (included in a routine $\mathrm{CBC}$ ) were used, which were found to be highly specific, sensitive and quite accurate method for detecting $\beta$-thalassemia trait.

\section{KEYWORDS}

Microcytic Hypochromic Anaemia, $\beta$-Thalassemia Trait, RBC Indices.

HOW TO CITE THIS ARTICLE: Jaswani P, Nigam RK, Kothari S. Clinico-haematological study of iron deficiency anaemia and $\beta$ thalassemia trait- predictive value of Sehgal index and various complete blood count indices to discriminate between iron deficiency anaemia and $\beta$-thalassemia trait and confirmation using haemoglobin electrophoresis/HPLC. J. Evolution Med. Dent. Sci. 2018;7(17):2118-2124, DOI: $10.14260 /$ jemds/2018/474

\section{BACKGROUND}

Anaemia is a global public health problem affecting populations in both developing and developed countries. According to the World Health Organization (WHO 2008) anaemia affects 1.62 billion people, which corresponds to $25 \%$ of the world population.[1]

'Financial or Other Competing Interest': None.

Submission 01-03-2018, Peer Review 06-04-2018,

Acceptance 12-04-2018, Published 23-04-2018.

Corresponding Author:

Dr. Rajendra Kumar Nigam,

E-116, Shahpura, Bhopal-462039,

Madhya Pradesh.

E-mail: dr.rajendranigam@gmail.com

DOI: $10.14260 /$ jemds $/ 2018 / 474$

\section{(c) $(1)$}

Iron deficiency anaemia is a common problem in India, more common in low socioeconomic group, especially in children. According to World Health Organization (WHO), the primary cause of anaemia is iron deficiency, especially in pregnant women and children.[2]

The most frequent hypochromic microcytic anaemias are iron deficiency anaemia and $\beta$-thalassemia. Wearherall et al reported that the thalassemia syndromes, among the most common heritable genetic diseases, are haemoglobinopathies characterised by diminished or absent production of normal $\alpha$-globin chains or $\beta$-globin chains. ${ }^{[3]}$ It is estimated that about $50 \%$ of the world's population with $\beta$-Thalassemia trait are in Southeast Asia.

Thalassemia traits are commonly misdiagnosed and treated as iron deficiency anaemia, in which iron is not 
required. It causes both economic and health burden to the patient. The excess iron has toxic effects on the body.

For proper management of a thalassaemic child, which includes enough and safe blood supply and best iron chelation therapy along with other medical and psychosocial management, the total expenditure on the management of thalassaemic children throughout the country is enormously high and most of the children in India suffering from thalassaemia are getting sub-optimal treatment. Thus, the prevention of beta-thalassemia major is more important aspect of disease management. ${ }^{[4]}$

A definitive differential diagnosis between $\beta$-Thalassemia trait and Iron deficiency anaemia is based on the result of HBA2 electrophoresis and ferritin calculations. The increase in haemoglobin $(\mathrm{Hb}) \mathrm{A}_{2}$ level is the most significant parameter in the identification of $\beta$-thalassaemia carriers. $(5,6)$

However, these investigations are money and time consuming and moreover areas where thalassemia is endemic often have low health care resources and these assays may not be generally available.

Thus, various discrimination indices have been proposed to distinguish between $\beta$-Thalassemia trait and Iron deficiency anaemia. These indices are derived from several simple red blood cell (RBC) indices like RBC count, mean corpuscular volume (MCV), mean corpuscular haemoglobin $(\mathrm{MCH}), \mathrm{RBC}$ distribution width (RDW) and haemoglobin (HB) as these are provided by electronic cell counters.

The purpose of using indices to discriminate anaemia is to detect subjects who have a high probability of requiring appropriate follow-up and to reduce unnecessary investigative costs.

\section{Aims and Objectives}

1. To study Red blood cell indices and Peripheral smear examination in microcytic hypochromic anaemia.

2. Estimation of $\mathrm{HbA} 2$ levels (Using Haemoglobin Electrophoresis/ HPLC) and serum Ferritin levels of all cases and confirmation of $\beta$-Thalassemia trait and Iron deficiency anaemia cases.

3. To evaluate the diagnostic value of various $\mathrm{RBC}$ indices in diagnosing $\beta$-Thalassemia trait and Iron deficiency anaemia.

4. To evaluate the Sehgal index and compare it to existing complete blood count based indices.

\section{MATERIALS AND METHODS}

It was a prospective, observational study carried out from January 2016 to June 2017. The present study was conducted in the Department of Pathology, Gandhi Medical College, Bhopal. A total of 100 patients (28 children and 72 adults) attending the outpatient departments of various specialties and diagnosed with mild microcytic hypochromic anaemia. The study was approved by Institutional Ethics Committee of Gandhi Medical College and Hamidia Hospital Bhopal (MP).

\section{Inclusion Criteria}

1. Patients had haemoglobin levels below $10 \mathrm{~g} / \mathrm{dL}$ for women and $12 \mathrm{~g} / \mathrm{dL}$ for men.

2. Mean corpuscular volume below $80 \mathrm{fL}$ and mean corpuscular haemoglobin (MCH) of $27 \mathrm{pg}$ for both genders. $[7,8,9]$

\section{Exclusion Criteria}

1. Patients with history of recent blood transfusion were excluded.

2. Patients less than one year of age were excluded.

3. Patients with malignancies or severe inflammatory/infectious diseases based on clinical data and personal information obtained from medical records were excluded.

4. Patients with other haemoglobinopathies (Sickle cell disease) were excluded.

The gold standard tests were serum ferritin and HPLC (High Performance Liquid Chromatography/ Haemoglobin Electrophoresis).

Diagnosis of Iron deficiency anaemia was made based on plasma ferritin values lower than $15 \mathrm{ng} \mathrm{mL}^{-1}$. Diagnosis of $\beta$ Thalassemia trait was made based on $\mathrm{HbA} 2$ levels of more than $3.5 \%$.

\section{Study Variables}

The study variables included in our study were age, sex, socio-economic status, dietary habits (Vegetarian or nonvegetarian), clinical complaints, clinical findings, peripheral smear findings, reticulocyte count, electronic cell counter readings, $\mathrm{RBC}$ indices, $\mathrm{HbA} 2$ values and serum ferritin values.

After obtaining informed consent, all the patients included in the study were subjected to detailed history taking (including old medical records), clinical examination and lab investigations.

Peripheral blood ( $5 \mathrm{~mL}$ ) was collected in tubes containing ethylenediaminetetraacetic acid (EDTA) at a final concentration of $1 \mathrm{mg} / \mathrm{mL}$ and the blood cell count results were obtained using automatic cell counter-

- $\quad$ Red blood cell (RBC) count and red blood cell distribution width (RDW) and other RBC indices were assessed using Mindray BC-3600 3-PART and Mindray BC-5300 5-PART Haematology Analyser available in our Central Pathology Laboratory.

- $\quad$ Serum ferritin and HbA2 values were determined in all.

- Haemoglobin electrophoresis using a fully automated capillary zone electrophoresis system (Sebia ${ }^{\circledR}$ Capillary 2 flex piercing)/ High-Performance Liquid chromatography using Bio-Rad Variant II was performed and $\mathrm{HbA} 2$ was measured.

- Another sample of the peripheral blood (5 mL) was collected in a plain vial (without anticoagulant) to evaluate serum ferritin values.

- Serum ferritin levels were determined by fully automated Bidirectionally Interfaced Chemiluminescent Immunoassay with reference ranges between 22 and $322 \mathrm{ng} / \mathrm{mL}$ for men and between 10 and $291 \mathrm{ng} / \mathrm{mL}$ for women.

- The cut-off value for HBA2 was kept at 3.5\%. Patients with HBA2 levels more than $3.5 \%$ were labelled as $\beta$ Thalassemia trait group and those with value less than $3.5 \%$ also serum ferritin $<22 \mathrm{ng} / \mathrm{mL}$ in males and $<10$ $\mathrm{ng} / \mathrm{mL}$ in female were labelled as Iron deficiency anaemia group. 
- Cases with concomitant $\beta$-Thalassemia trait and Iron deficiency anaemia and having other abnormal $\mathrm{Hb}$ variant were excluded from our study.

- Values of HB, RBC count, MCV, MCH and RDW obtained from the electronic cell counter were used to calculate discrimination indices by various mathematical formulae as given in Table below.

\begin{tabular}{|c|c|c|}
\hline Discriminant Index & Calculation & Cut-off Value \\
\hline Mentzer(10) & $\mathrm{MCV} / \mathrm{RBC}$ & 13 \\
\hline Srivastava(11) & $\mathrm{MCH} / \mathrm{RBC}$ & 3.8 \\
\hline $\begin{array}{l}\text { Shine and Lal (S and } \\
\qquad \mathrm{L})(12)\end{array}$ & $\mathrm{MCV}^{2} \times \mathrm{MCH} / 100$ & 1530 \\
\hline $\begin{array}{l}\text { England and Fraser } \\
\quad(\mathrm{E} \text { and } \mathrm{F})^{(13)}\end{array}$ & $\begin{array}{c}\mathrm{MCV}-\mathrm{RBC}-(5 \times \mathrm{Hb})- \\
3.4 \\
\end{array}$ & 0 \\
\hline $\begin{array}{l}\text { Green and King (G } \\
\text { and } K)^{(14)}\end{array}$ & $\mathrm{MCV}^{2} \times \mathrm{RDW} / 100 \mathrm{Hb}$ & 65 \\
\hline Ricerca(15) & RDW/ RBC & 4.4 \\
\hline Ehsani(16) & $\mathrm{MCV}-(10 \times \mathrm{RBC})$ & 15 \\
\hline Sirdah(17) & $\mathrm{MCV}-\mathrm{RBC}-(3 \mathrm{xHb})$ & 27 \\
\hline Sehgal Index ${ }^{(18)}$ & $\mathrm{MCV}^{2} / \mathrm{RBC}$ & 972 \\
\hline \multicolumn{3}{|c|}{$\begin{array}{c}\text { Table 1. Mathematical Formulae to Calculate } \\
\text { Discrimination Indices }\end{array}$} \\
\hline
\end{tabular}

\section{Statistical Analysis}

Qualitative data was expressed as number and percentage and was analysed using Chi-square test. Quantitative data was expressed as mean and standard deviation and was analysed using ' $\mathrm{t}$ ' test. Sensitivity, specificity, positive predictive value (PPV), negative predictive value (NPV) and Youden's index (YI) [Youden's index= (Sensitivity + specificity)-100]. ROC curve with AUC were calculated for all the discrimination indices using SPSS 8.0. $P$ values less than 0.05 were considered significant.

\section{RESULTS}

A total 100 patients with hypochromic microcytic anaemia were included in this study comprising 36 males and 64 females; of which 85 cases were of Iron deficiency anaemia IDA (27 males and 58 females), and 15 cases were of $\beta$ Thalassemia trait ( 09 males and 06 females).

In our study, age of patients included varies from 1 year to 65 years of age with maximum number of patients in age group of 16 to 30 years of age.

Of 36 male cases, maximum number of cases (58\%) belonged to age group of 1 - 15 years of age.

Of 64 female cases, maximum number of cases belonged to age group of 16 to 30 years of age (35\%) followed by age group of 1 to 15 years (31\%) followed by 31 to 45 years of age group (28\%).

Most of the microcytic hypochromic anaemic females belonged to reproductive age group.

In our study, out of 100 cases which included 85 cases of Iron deficiency anaemia and 15 cases of $\beta$-Thalassemia trait.

In 15 cases of $\beta$-Thalassemia trait, nine $(60 \%)$ cases were male and six cases (40\%) were female.

In 85 cases of Iron deficiency anaemia, 27 cases (31.7\%) were male and 58 cases $(68.2 \%)$ were female.

In our study out of 15 cases of $\beta$-Thalassemia trait, 9 cases $(60 \%)$ belonged to Muslim community and the rest of 6 cases (40\%) belonged to Hindu community.

Similarly, in total of 85 cases of Iron deficiency anaemia, 25 cases $(29.4 \%)$ belonged to Muslim religion and the remaining 60 cases (70.6\%) belonged to Hindu religion.

In our study, among Iron deficiency anaemia cases (total of 85 cases) 60 cases had vegetarian diet intake and 25 cases had non-vegetarian diet intake.

For $\beta$-Thalassemia trait cases (total of 15 cases), 07 cases had vegetarian diet intake and 08 cases had non-vegetarian diet intake.

Majority of the patients in the present study had weakness/ fatigue (89\%) followed by palpitation as the next common complaint.

Pallor was the most common sign observed in both $\beta$ Thalassemia trait and Iron deficiency anaemia group. In $\beta$ Thalassemia trait cases $46.6 \%$ cases had pallor and in Iron deficiency anaemia $64.7 \%$ cases showed pallor.

Mild-to-moderate Anisopoikilocytosis was seen in 31.7\% cases of Iron deficiency anaemia as compared to $26.6 \%$ cases of $\beta$-Thalassemia trait. In $20 \%$ of the $\beta$-Thalassemia trait cases, no Anisopoikilocytosis was seen.

Target cells were more frequently found in BTT $(26 \%)$ cases as compared to IDA cases (14.1\%).

\begin{tabular}{|c|c|c|c|}
\hline RBC Indices & $\begin{array}{c}\text { B-TT } \\
\mathbf{( N = 1 5 )}\end{array}$ & $\begin{array}{c}\text { IDA } \\
\mathbf{( N = 8 5 )}\end{array}$ & P value \\
\hline MCV (Mean \pm SD) & $61.5 \pm 1.8$ & $64.5+5.82$ & $<0.001$ \\
\hline MCH (Mean \pm SD) & $18.8 \pm 0.5$ & $19.9+3.31$ & $<0.001$ \\
\hline RDW (Mean \pm SD) & $16.1 \pm 0.9$ & $19.33 \pm 3.00$ & 0.004 \\
\hline $\begin{array}{c}\text { RBC Count Males (Mean } \\
\pm \text { SD) }\end{array}$ & $5.61 \pm 0.34$ & $4.09 \pm 0.39$ & $<0.05$ \\
\hline $\begin{array}{c}\text { RBC Count Females } \\
\text { (Mean } \pm \text { SD) }\end{array}$ & $5.68 \pm 0.55$ & $4.13 \pm 0.37$ & $<0.05$ \\
\hline $\begin{array}{c}\text { Reticulocyte Count } \\
\text { (Mean } \pm \text { SD) }\end{array}$ & $2.67 \pm 0.60$ & $1.89 \pm 0.27$ & $<0.001$ \\
\hline
\end{tabular}

Table 2. Comparison of RBC Indices: BTT and IDA

In $\beta$-Thalassemia trait group, the mean MCV and $\mathrm{MCH}$ were $61.5 \pm 1.8$ and $18.1+0.5$ respectively, which were lower than those found in the IDA group $(64.5+5.82$ and $19.9+$ 3.31 respectively) ( $p<0.05$, significant).

The mean RDW values were increased in both the groups, but the Iron deficiency anaemia group showed the values to be higher $(19.33+3.00)$ as compared to the $\beta$-TT group $(16.1$ $+0.9)(\mathrm{p}<0.05$, significant $)$.

The mean RBC count in $\beta$-Thalassemia trait group was definitely higher ( $5.61 \pm 0.34$ in males; $5.68 \pm 0.55$ in females) as compared to the Iron deficiency anaemia group (4.09 \pm 0.39 in males and $4.13 \pm 0.37$ in females) $(\mathrm{p}<0.05$, significant).

Individuals with the $\beta$-Thalassemic trait presented with slightly higher reticulocyte counts ( $\mathrm{p}$-value $<0.05$ ) compared to Iron deficiency anaemia cases.

The mean values for serum ferritin were much lower in Iron deficiency anaemia group as compared to those in the $\beta$ Thalassemia trait group.

\begin{tabular}{|c|c|c|c|}
\hline S. Ferritin & ß-TT (N=15) & IDA (N=85) & P value \\
\hline Males (Mean \pm SD) & $34.19 \pm 16.18$ & $16.066 \pm 2.84$ & $<0.001$ \\
\hline Range & $21-73$ & $9.2-20.1$ & \\
\hline $\begin{array}{c}\text { Females (Mean } \pm \\
\text { SD) }\end{array}$ & $18.166 \pm 5.17$ & $9.02 \pm 2.05$ & $<0.001$ \\
\hline Range & $11.5-26.8$ & $6.7-10.2$ & \\
\hline \multicolumn{4}{|l}{} \\
\hline
\end{tabular}




\begin{tabular}{|c|c|c|c|}
\hline $\mathrm{HbA2}$ & B-TT $(\mathrm{N}=15)$ & IDA $(\mathrm{N}=85)$ & P value \\
\hline $2-3.5$ & 0 & 84 & \multirow{5}{*}{$<0.001$} \\
\hline $3.6-5$ & 13 & 1 & \\
\hline $5.1-6.5$ & 2 & 0 & \\
\hline Mean \pm SD & $3.8 \pm 0.53$ & $2.02 \pm 0.173$ & \\
\hline Range & $4.5-6.2$ & $2-3.4$ & \\
\hline
\end{tabular}

On the basis of HBA2 levels, 15 patients having HBA2 more than $3.5 \%$ were grouped into $\beta$-Thalassemia trait group. Rest 85 patients having HBA2 less than 3.5\% were included in the Iron deficiency anaemia group. The mean values for HBA2 in $\beta$-TT group were $3.8 \pm 0.53$ and those in the Iron deficiency anaemia group were $2.02 \pm 0.173$ $(\mathrm{p}<0.0001$, significant).

\begin{tabular}{|c|c|c|c|c|c|c|c|}
\hline Sl. No. & Indices & Sensitivity & Specificity & PPV & NPV & $\begin{array}{c}\text { Youden's } \\
\text { Index }\end{array}$ & $P$ value \\
\hline 1 & $\begin{array}{c}\text { Mentzer Index } \\
\text { B-TT } \\
\text { IDA } \\
\end{array}$ & $\begin{array}{l}81.25 \\
97.62 \\
\end{array}$ & $\begin{array}{l}97.62 \\
81.25 \\
\end{array}$ & $\begin{array}{l}86.67 \\
96.47 \\
\end{array}$ & $\begin{array}{l}96.47 \\
86.67 \\
\end{array}$ & 90.98 & $\mathrm{P}=0.0106$ \\
\hline 2 & $\begin{array}{c}\text { Srivastava Index } \\
\text { ß-TT } \\
\text { IDA } \\
\end{array}$ & $\begin{array}{r}93.33 \\
96.47 \\
\end{array}$ & $\begin{array}{l}96.47 \\
93.33 \\
\end{array}$ & $\begin{array}{c}82.35 \\
98.8 \\
\end{array}$ & $\begin{array}{r}98.8 \\
82.35 \\
\end{array}$ & 89.8 & $\mathrm{P}=0.0170$ \\
\hline 3 & $\begin{array}{c}\text { Shine and Lal Index } \\
\text { ß-TT } \\
\text { IDA } \\
\end{array}$ & $\begin{array}{c}100 \\
16.47 \\
\end{array}$ & $\begin{array}{c}16.47 \\
100 \\
\end{array}$ & $\begin{array}{c}17.44 \\
100 \\
\end{array}$ & $\begin{array}{c}100 \\
17.44 \\
\end{array}$ & 16.47 & $\mathrm{P}<0.0001$ \\
\hline 4 & $\begin{array}{c}\text { England and Fraser Index } \\
\text { B-TT } \\
\text { IDA }\end{array}$ & $\begin{array}{c}60 \\
100\end{array}$ & $\begin{array}{c}100 \\
60\end{array}$ & $\begin{array}{c}100 \\
93.41\end{array}$ & $\begin{array}{c}93.41 \\
100\end{array}$ & 60 & $\mathrm{P}<0.0001$ \\
\hline 5 & $\begin{array}{c}\text { Green and King Index } \\
ß-T T \\
\text { IDA } \\
\end{array}$ & $\begin{array}{c}66.67 \\
100 \\
\end{array}$ & $\begin{array}{c}100 \\
66.67 \\
\end{array}$ & $\begin{array}{c}100 \\
94.44\end{array}$ & $\begin{array}{c}94.44 \\
100 \\
\end{array}$ & 66.67 & $\mathrm{P}<0.0001$ \\
\hline 6 & $\begin{array}{c}\text { Ricera Index } \\
\text { ß-TT } \\
\text { IDA } \\
\end{array}$ & $\begin{array}{c}100 \\
60 \\
\end{array}$ & $\begin{array}{c}60 \\
100 \\
\end{array}$ & $\begin{array}{c}30.61 \\
100 \\
\end{array}$ & $\begin{array}{c}100 \\
30.61 \\
\end{array}$ & 60 & $\mathrm{P}<0.0001$ \\
\hline 7 & $\begin{array}{c}\text { Ehsani Index } \\
\text { ß-TT } \\
\text { IDA } \\
\end{array}$ & $\begin{array}{l}93.33 \\
96.47 \\
\end{array}$ & $\begin{array}{l}96.47 \\
93.33 \\
\end{array}$ & $\begin{array}{c}82.35 \\
98.8 \\
\end{array}$ & $\begin{array}{r}98.8 \\
82.35 \\
\end{array}$ & 89.8 & $\mathrm{P}=0.0170$ \\
\hline 8 & $\begin{array}{c}\text { Sirdah Index } \\
\text { ß-TT } \\
\text { IDA } \\
\end{array}$ & $\begin{array}{c}53.33 \\
100 \\
\end{array}$ & $\begin{array}{c}100 \\
53.33 \\
\end{array}$ & $\begin{array}{c}100 \\
92.39 \\
\end{array}$ & $\begin{array}{c}92.39 \\
100\end{array}$ & 53.33 & $P<0.0001$ \\
\hline 9 & $\begin{array}{c}\text { Sehgal Index } \\
\text { ß-TT } \\
\text { IDA } \\
\end{array}$ & $\begin{array}{c}100 \\
90.59 \\
\end{array}$ & $\begin{array}{c}90.59 \\
100 \\
\end{array}$ & $\begin{array}{c}65.22 \\
100 \\
\end{array}$ & $\begin{array}{c}100 \\
65.22 \\
\end{array}$ & 90.59 & $\mathrm{P}=0.0430$ \\
\hline 10 & $\begin{array}{c}\text { RBC Index } \\
\text { ß-TT } \\
\text { IDA } \\
\end{array}$ & $\begin{array}{l}93.33 \\
76.47 \\
\end{array}$ & $\begin{array}{l}76.47 \\
93.33 \\
\end{array}$ & $\begin{array}{l}41.18 \\
98.48 \\
\end{array}$ & $\begin{array}{l}98.48 \\
41.18 \\
\end{array}$ & 69.8 & $\mathrm{P}=0.14$ \\
\hline
\end{tabular}

Table 4. Sensitivity, Specificity, Positive Predictive Value (PPV), Negative Predictive Value (NPV) and Youden's Index (YI) of each Discriminating Function (DF) Index

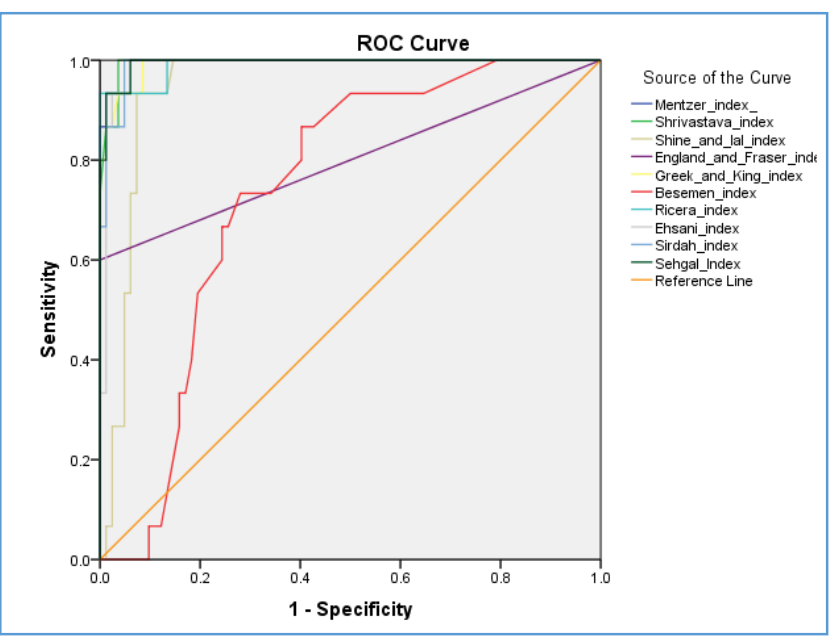

\begin{tabular}{|c|c|}
\hline \multicolumn{2}{|c|}{ Area Under the Curve } \\
\hline Index & Area \\
\hline Mentzer_Index & 0.995 \\
\hline Shrivastava_Index & 0.994 \\
\hline Shine_and_Lal_Index & 0.945 \\
\hline England_and_Fraser_Index & 0.800 \\
\hline Greek_and_King_Index & 0.991 \\
\hline Besemen_Index & 0.739 \\
\hline Ricera_Index & 0.991 \\
\hline Ehsani_Index & 0.988 \\
\hline Sirdah_Index & 0.991 \\
\hline Sehgal_Index & 0.994 \\
\hline
\end{tabular}

As is evident from the results shown in table above: The highest values for Youden's index were shown by Mentzer index (90.98) and Sehgal index (90.59\%) and lowest values for Youden's index was shown by Shine and Lal index (16.47\%). 
In the present study the Sehgal index showed a reasonably high sensitivity, specificity and good Youden's index of $100 \%, 90.59 \%$ and $90.59 \%$ respectively.

This was followed by Mentzer index which showed sensitivity, specificity and Youden's index of $81.25 \%, 97.65 \%$ and $90.9 \%$ respectively.

This was followed by Ehsani et al index and Shrivastava index, each showed sensitivity and specificity and Youden's index of $93.3 \%, 96.4 \%$ and $89.8 \%$ respectively.

\section{DISCUSSION}

The clinical features of mild iron deficiency anaemia and thalassemia trait are usually similar and consists of fatigue, palpitations and anorexia. $\beta$-Thalassemia trait cases generally have mild anaemia with mild decrease in Haemoglobin value. In the present study, mean RBC count was higher in $\beta$ Thalassemia trait as compared to iron deficiency anaemia, the mean MCV count and mean MCH were lower and comparable to the findings in other studies.

In the present study, mean RDW count was $13.3 \pm 2.5 \%$ in $\beta$-Thalassemia trait and Iron deficiency anaemia as compared to $16.62 \pm 3.45 \%$ in IDA confirming that the red cells in cases of $\beta$-Thalassemia trait are indeed microcytic homogenous compared to iron deficiency anaemia.

Target cells and basophilic stippling were encountered more frequently in $\beta$-Thalassemia trait and Iron deficiency anaemia. Peripheral blood film examination usually reveals microcytosis with mild anisocytosis, target cells and fine basophilic stippling than with IDA given the same level of anaemia.

The findings of peripheral smears were in concordance with other studies (13) in the literature.

Individuals with the $\beta$-Thalassemic trait presented with slightly higher reticulocyte counts ( $p$-value $<0.05)$ compared to Iron deficiency anaemia cases. These results are in agreement with those reported by Noronha and Grotto et al.

Though, the sensitivity of RBC count for beta-thalassemia trait was $93.05 \%$, it showed a specificity and Youden's index of only $76.4 \%$ and $69.4 \%$ respectively. So according to our results, $\mathrm{RBC}$ count alone cannot be taken as a reliable index to distinguish between beta-thalassemia trait and Iron deficiency anaemia.

RDW, a measure of the degree of variation in red cell size has been reported to be a good discrimination index to differentiate between $\beta$-Thalassemia trait and Iron deficiency anaemia. But in our study the values were elevated in both the groups, though they were slightly higher in the Iron deficiency anaemia group. Our results concur well with results of who found that RDW alone is reasonable, but not sufficiently specific or sensitive enough to differentiate between $\beta$-Thalassemia trait and Iron deficiency anaemia.

In the present study the Sehgal index showed a reasonably high sensitivity, specificity and good Youden's index of $100 \%, 90.59 \%$ and $90.59 \%$ respectively.

This was followed by Mentzer index which showed sensitivity, specificity and Youden's index of 93.3\%, 97.65\% and $90.9 \%$ respectively.

This was followed by Ehsani et al index and Shrivastava index which showed sensitivity, specificity and Youden's index of $93.3 \%, 96.4 \%$ and $89.8 \%$ respectively. Rathod et al found that formulae presented by Shine and Lal, Srivastava and Mentzer had good discriminative function.(19) Alfadhli et al compared nine discriminant functions in patients with microcytic anaemia and found a Youden's index of 54.9\% for Srivastava index.[20]

Ehsani et al in 2009 showed that the best discrimination index according to Youden's criteria was the Mentzer index (90.1\%) followed by the Ehsani et al index (85.5\%). In their study, the Mentzer and Ehsani et al indices were able to correctly diagnose $94.7 \%$ and $92.9 \%$ of cases, respectively.[21]

Rahim and Keikhaei in 2009 examined the diagnostic accuracy of 10 indices in 153 patients with $\beta$-Thalassemia trait and 170 patients with Iron deficiency anaemia. They found that the Mentzer index had 85\% sensitivity, 93\% specificity and 79\% Youden's index.[22] Similar results (Mentzer index: sensitivity, 90.9\%; specificity, 80.3\%) were found by Ghafouri et al.[23]

In the present study the England and Fraser index had the highest specificity of $100 \%$, but the Youden's index was $60 \%$. The Sirdah Index and England and Fraser index demonstrated the lowest sensitivity of $53.33 \%$ and $60 \%$ respectively, which means Sirdah index missed about $47 \%$ of $\beta$-Thalassemia trait cases and England and Fraser Index missed $40 \% \quad \beta$ Thalassemia trait cases.

Shine and Lal index showed a Youden's index of only $16.4 \%$ and proved to be ineffective in differentiating between $\beta$-Thalassemia trait and Iron deficiency anaemia.

In the present study the Sirdah index demonstrated a sensitivity, specificity and Youden's index of 53.3\%, 100\% and $53.3 \%$ respectively. Vehapoglu et al 2014[24] found sensitivity, specificity and Youden's index to be $85.7 \%, 79.4 \%$ and $65.0 \%$ respectively.

Sirdah et al conducted a study in 2007 to evaluate the reliability of different RBC indices and their formulas (MCVRBC-3.Hb) in Palestinian population and concluded that their formulas (Sirdah), Green and King index and RDW have the highest accuracy in differentiating between the $\beta$ Thalassemia trait and Iron deficiency anaemia.(11)

\begin{tabular}{|c|c|c|c|}
\hline Study & Year & $\begin{array}{c}\text { Discriminant Function with } \\
\text { highest Youden's Index }\end{array}$ & $\begin{array}{c}\text { Youden's } \\
\text { Index }\end{array}$ \\
\hline $\begin{array}{c}\text { AlFadhli } \\
\text { et al (25) }\end{array}$ & 2007 & England and Fraser & $98.2 \%$ \\
\hline $\begin{array}{c}\text { Ntaios et al } \\
(26)\end{array}$ & 2007 & Greek and King Index & $70.86 \%$ \\
\hline $\begin{array}{c}\text { Ehsani et al } \\
\text { (16) }\end{array}$ & 2009 & Mentzer index & 90.1 \\
\hline $\begin{array}{c}\text { Rahim and } \\
\text { Keikhaei(27) }\end{array}$ & 2009 & Mentzer index & $79 \%$ \\
\hline $\begin{array}{c}\text { Ferrara } \\
\text { et al(28) }\end{array}$ & 2010 & England and Fraser index & $64.2 \%$ \\
\hline $\begin{array}{c}\text { Urrechaga } \\
\text { et al(29,30) }\end{array}$ & 2011 & Greek and King Index & $80.9 \%$ \\
\hline $\begin{array}{c}\text { Vehapoglu } \\
\text { et al(31) }\end{array}$ & 2014 & Sirdah Index & $65.0 \%$ \\
\hline $\begin{array}{c}\text { Present } \\
\text { Study }\end{array}$ & 2017 & Mentzer Index and Sehgal & $\begin{array}{c}90.9 \% \text { and } \\
90.59 \% \\
\text { respectively }\end{array}$ \\
\hline Table 5. & Index & \\
\hline
\end{tabular}

Table 5. Comparison of Youden's Index of Present Study with the Youden's Index of Previous Studies

\section{CONCLUSION}

In the Indian population, $\beta$-Thalassemia trait and Iron deficiency anaemia are common causes of microcytic hypochromic anaemia. The real danger of non-diagnosis and misdiagnosis of carriers of thalassemia trait is potential 
homozygous offspring. Appropriate screening, detection of patients and counseling of couples at risk are the most important measures for the reduction of morbidity and mortality.

Although, confirmatory test is $\mathrm{HbA} 2$ level estimation, but our present study proved that a discriminant formula or CBCbased index with a combination of high sensitivity and specificity for detecting $\beta$-Thalassemia trait is a very useful tool in the investigation of microcytic hypochromic anaemia in developing countries like India, where nutritional deficiencies and thalassemia are present with higher prevalence.

This study found that the "Sehgal Index" and "Mentzer Index" met the requirements of both high sensitivity and high specificity to predict $\beta$-Thalassemia trait and Iron deficiency anaemia.

These indices can be applied for screening purposes in large population.

\section{REFERENCES}

[1] Lopez A, Cacoub P, Macdougall IC, et al. Iron deficiency anaemia. The Lancet 2016;387(10021):907-16.

[2] Angastiniotis M, Modell B. Global epidemiology of hemoglobin disorders. Ann N Y Acad Sci 1998;850(1):251-69.

[3] Weatherall DJ, Clegg JB. Inherited haemoglobin disorders: an increasing global health problem. Bull World Health Organ 2001;79(8):704-12.

[4] Ntaios G, Chatzinikolaou A, Saouli $Z$, et al. Discrimination indices as screening tests for $\beta$ thalassemic trait. Annals of Hematology 2007;86(7):487-91.

[5] Mosca A, Paleari R, Ivaldi G, et al. The role of haemoglobin $\mathrm{A}(2)$ testing in the diagnosis of thalassaemias and related haemoglobinopathies. Journal of Clinical Pathology 2009;62(1):13-7.

[6] Qureshi TZ, Anwar M, Ahmed S, et al. Serum ferritin levels in carriers of $\beta$-thalassaemia trait. Acta Haematologica 1995;94(1):7-9.

[7] Bain B. Dacie and Lewis practical hematology. Chapter - 2.11 th edn. Edinburgh: Churchill Livingstone 2011: p. 14.

[8] Bain BJ. Blood cells: a practical guide. Chapter - 5. $4^{\text {th }}$ edn. Wiley-Blackwell 2006: p. 203.

[9] Singh T. Atlas and textbook of hematology. Chapter - 3. $3^{\text {rd }}$ edn. Avichal Publishing Company 2014: p. 87.

[10] Mentzer WC. Differentiation of iron deficiency from thalassaemia trait. Lancet 1973;1(7808):882.

[11] Srivastava PC. Differentiation of thalassaemia minor from iron deficiency. The Lancet 1973;2:154-5.

[12] Shine I, Lal S. A strategy to detect $\beta$ thalassaemia minor. The Lancet 1977;1(8013):692-4.

[13] Thomas C, Thomas L. Biochemical markers and hematologic indices in the diagnosis of functional iron deficiency. Clinical Chemistry 2002;48(7):1066-76.

[14] Green R, King R. A new red cell discriminant incorporating volume dispersion for differentiating iron deficiency anemia from thalassemia minor. Blood Cells 1989;15(3):481-95.
[15] Ricerca BM, Storti S, d'Onofrio G, et al. Differentiation of iron deficiency from thalassaemia trait: a new approach. Haematologica 1987;72(5):409-13.

[16] Ehsani MA, Shahgholi E, Rahiminejad MS, et al. A new index for discrimination between iron deficiency anemia and beta-thalassemia minor: results in 284 patients. Pakist J Biol Sci 2009;12(5):473-5.

[17] Sirdah M, Tarazi I, Al Najjar E, et al. Evaluation of the diagnostic reliability of different RBC indices and formulas in the differentiation of the betathalassaemia minor from iron deficiency in Palestinian population. Int J Lab Hematol 2008;30(4):324-30.

[18] Sehgal K, Mansukhani P, Dadu T, et al. Sehgal index: a new index and its comparison with other complete blood count-based indices for screening of beta thalassemia trait in a tertiary care hospital. Indian Journal of Pathology and Microbiology 2015;58(3):310-15.

[19] Rathod DA, Kaur A, Patel V, et al. Usefulness of cell counter-based parameters and formulas in detection of $\beta$-thalassemia trait in areas of high prevalence. American Journal of Clinical Pathology 2007;128(4):585-9.

[20] Mirbehbahani NB, Rashidbaghan A, Mazji M, et al. National approach to premarital diagnosis of trait thalassemia and silent carriers. International Journal of Clinical Medicine 2013;4(2):91-5. doi: 10.4236/ijcm.2013.42017.

[21] Lafferty JD, Crowther MA, Ali MA, et al. The evaluation of various mathematical $r b c$ indices and their efficacy in discriminating between thalassemic and nonthalassemic microcytosis. Am J Clin Pathol 1996;106(2):201-5.

[22] Bentley SA, Ayscue LH, Watson JM, et al. The clinical utility of discriminant functions in the differential diagnosis of microcytic anemias. Blood Cells 1989;15(3):575-82.

[23] Lorey F, Charoenkwan P, Witkowska HE, et al. Hb H hydrops foetalis syndrome: a case report and review of literature. Br J Haematol 2001;115(1):72-8.

[24] Piplani S, Madan M, Mannan R, et al. Evaluation of various discrimination indices in differentiating iron deficiency anemia and beta thalassemia trait: a practical low cost solution. Annals of Pathology and Laboratory Medicine 2016;3(Suppl):A-551-A-9.

[25] Al-Fadhli SM, Al-Awadhi AM, Al-Khaldi D, et al. Validity assessment of nine discriminant functions used for the differentiation between Iron deficiency anemia and thalassemia minor. Journal of Tropical Pediatrics 2007;53(2):93-7.

[26] Ntaios G, Chatzinikolaou A, Saouli Z, et al. Discrimination indices as screening tests for betathalassemic trait. Ann Hematol 2007;86(7):487-91.

[27] Rahim F. Correlation of beta-thalassemia mutations with alpha-thalassemia: an experience of the southwestern region of Iran. Hematology 2010;15(6):430-3.

[28] Ferrara M, Capozzi L, Russo R, et al. Reliability of red blood cell indices and formulas to discriminate between $\beta$ thalassemia trait and iron deficiency in children. Hematology 2010;15(2):112-5. 


\section{Jemds.com}

[29] Urrechaga E, Borque L, Escanero JF. The role of automated measurement of RBC subpopulations in differential diagnosis of microcytic anemia and $\beta$ thalassemia screening. American Journal of Clinical Pathology 2011;135(3):374-9.

[30] Urrechaga E. Discriminant value of \% microcytic/\% hypochromic ratio in the differential diagnosis of microcytic anemia. Clin Chem Lab Med 2008;46 (12):1752-8.

\section{Original Research Article}

[31] Vehapoglu A, Ozgurhan G, Demir AD, et al. Hematological indices for differential diagnosis of beta thalassemia trait and iron deficiency anemia. Article ID 576738, Anemia 2014;(2014): p. 7. doi: $10.1155 / 2014 / 576738$ 